\title{
Effectiveness Practice Teaching Higher Order Thinking Skils (Hots) in Subject Islamic Education Primary School
}

\author{
Mohd Syaubari Bin Othman, Nor Anisa Binti Musa
}

To Link this Article: http://dx.doi.org/10.6007/IJARBSS/v11-i4/8858

DOI:10.6007/IJARBSS/v11-i4/8858

Received: 08 February 2021, Revised: 15 March 2021, Accepted: 02 April 2021

Published Online: 29 April 2021

In-Text Citation: (Othman \& Musa, 2021)

To Cite this Article: Othman, M. S. Bin, \& Musa, N. A. B. (2021). Effectiveness Practice Teaching Higher Order Thinking Skils (Hots) in Subject Islamic Education Primary School. International Journal of Academic Research in Business and Social Sciences, 11(4), 1162-1174.

\section{Copyright: @ 2021 The Author(s)}

Published by Human Resource Management Academic Research Society (www.hrmars.com)

This article is published under the Creative Commons Attribution (CC BY 4.0) license. Anyone may reproduce, distribute, translate and create derivative works of this article (for both commercial and non-commercial purposes), subject to full attribution to the original publication and authors. The full terms of this license may be seen at: http://creativecommons.org/licences/by/4.0/legalcode

Vol. 11, No. 4, 2021, Pg. 1162 - 1174

Full Terms \& Conditions of access and use can be found at http://hrmars.com/index.php/pages/detail/publication-ethics 


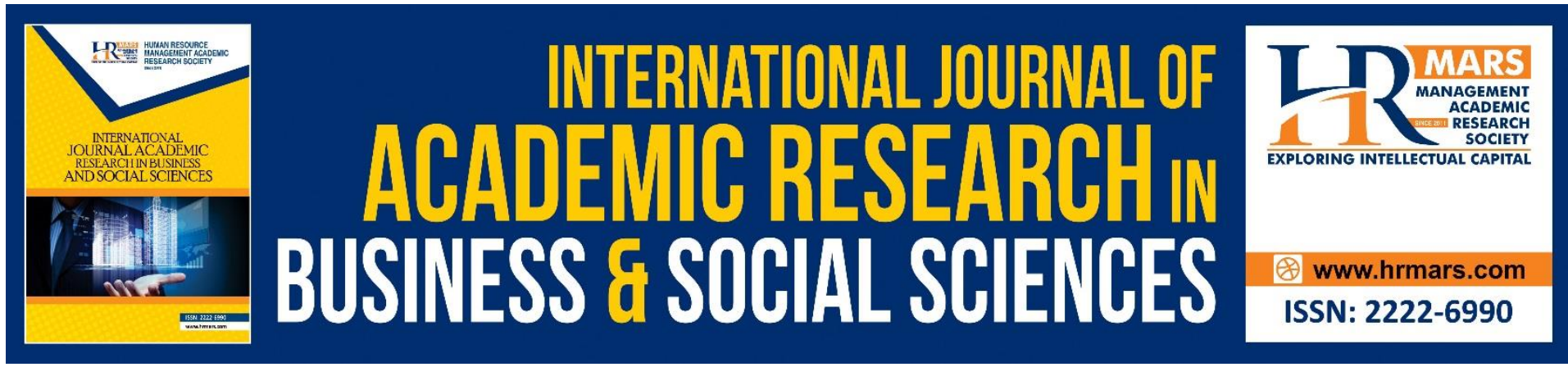

\title{
Effectiveness Practice Teaching Higher Order Thinking Skils (Hots) in Subject Islamic Education Primary School
}

\author{
Mohd Syaubari Bin Othman Ph.D \\ Fakulti Pembangunan Manusia,, Universiti Pendidikan Sultan Idris, Tanjung Malim, Perak \\ Email: syaubari@fpm.upsi.edu.my \\ Nor Anisa Binti Musa \\ Bahagian Pendidikan Islam, Kementerian Pelajaran Malaysia \\ Email: anisa@moe.gov.my
}

\begin{abstract}
This study aims to identify the initial effectiveness of teaching primary school teachers of Islamic education based on higher order thinking skills (HOTS). The study involved Perak but this study is an initial survey prior to a broader study on the run. Component higher-order thinking such as skill appeal vary, skills collating sequence, skills forecasting, skills definition and skills to create the analogy that in view of the three main components of initial teacher teaching the lesson planning, setting teaching objectives and induction set is selected as the conceptual framework. This study used a descriptive analysis (through a questionnaire). All of this data collection instrument developed by the researcher with the modification of the instrument KBAT Ministry of Education and experts involved and its contents confirmed by a reference panel of experts. Cronbach alpha reliability level value obtained is high at between (0.82173). A total of 400 teachers of Islamic education randomly selected to answer the questionnaire. Data were analyzed descriptively using percentages frequency and min. Overall, the study found the practice teaching based on higher order thinking skills is at the high level by means of the whole $(4: 43)$ and based on components of teaching practice which consists of teaching plans which recorded $\min (4.45)$, setting learning objectives listed min (4.44) and set induction recorded $\min (4: 40)$. Implications and recommendations can give a benefit to ministries, schools, teachers and the community in improving the level of teaching practices based on higher order thinking skills (HOTS) as envisaged in the Education Development Plan 2013-2025
\end{abstract}

Keywords: Beginning Teaching Practice Islamic Education, Higher Order Thinking Skills, Primary.

\section{Introduction}

Higher order thinking skills is a skill that requires organizing thoughts based on the ability to describe, interpret, create, reflect and correlate with the current situation. This HOTS emphasis in the education system is an extension of the implementation of critical thinking 
skills and creative (CCTS), which was implemented in 1993. The implementation process HOTS Malaysia is sourced bloom taxonomy and modified by Anderson through the top four hierarchy apply, analyze, evaluate and create.

The transformation of the educational curriculum in Malaysian Education Development Plan (2013-2025) places great emphasis on the concept of higher order thinking skills (HOTS) capable of producing a generation has the ability in critical and creative thinking. This approach was introduced to achieve the ultimate goal of education produce more students who have a high level of cognitive ability through active learning pedagogy for the teaching and learning. However, the goal has not yet been fully achieved, the various approaches have been introduced to produce human capital that is intelligent, creative and innovative to meet the challenges of the 21st century so that the country can compete on the world stage. According to (Amabile et al., 2010).

"If you want potential students to think and to solve the problem we need to start preparing assignments complex assignments that high thinking"

So this notion coincides with the emphasis given by Islam, namely the ability of the mind is a key element in the formation of students' holistic balance between academic excellence and steadiness of character. Islam emphasizes the optimum use of reasonable use for hundreds of years before the western introduce, but it's not been wrought and transformed it shows that western scientists who explore these higher-order thinking. This is evident from the Quran. This is in support of expression by Muaz Bin Jabal, when asked by the Prophet s.a.w:

"How will you judge if asked matter to you?" Mu'az said, "I will decide the matter in accordance with the law of God (the Book). When I did not find in the Al-Quran, I will decide with the Sunnah of the Messenger of Allah, I will do ijtihad in my abilities." (Ail and Abdullah, 2016). The transformation process of Islamic Education was formulated based on the implementation of teaching in schools through modification involves the ability of the curriculum, the establishment of school culture, improving teachers' knowledge and the ability of students to apply for any content learning gained to aim. The introduction of teaching and learning oriented HOTS can implemented effectively and lead to a steady appreciation of the faith among the students (Aminullah, 2015)

\section{Background Research}

\section{Higher Order Thinking Skills (HOTS)}

Higher Order Thinking Skills by Brookhart (2010) is questioned, seeks, understand and analyze things to understand the thinking of themselves and others. Among the activities that can be carried to higher order thinking skills (HOTS) is through active thinking, look at the context of the environment based on different perspectives and develop each idea regularly Brookhart, (2010). So in this study will use a variable that is expertise in implementing HOTS in teaching as follows.

\section{Making Skills Category}

These skills require the ability of students to develop an understanding of the differences that exist in any content categorized as acts of worship or religious customs that are categorized. And be understanding of the needs of students with knowledge of the contents of religious practices and traditions as found in the teaching content (Çelik, Arikan and Caner, 2013) 


\section{Skills Arrange in Order}

Organizers sequence is generated through the skills of critical thinking and organized. This preparation involves either from the abstract to the clarity, easy to difficult, public and priorities specific to the habit. This preparation is done by collecting the entire contents of these skills requires preparation and analysis ensure that high in order to do is to coincide with the structure of the science involved (Hashim, 2005)

\section{Skills to Make Predictions.}

Abilities to assume things are expected from the approach we use is through the terms that have been set. The ability to anticipate the need to analyze and assess the entire item to the findings should lead to the development. The ability to make predictions can be civilizing framework for analysis is part of the students (Hennessey, 2019)

\section{Abilities generate ideas}

The ability of students to develop the facts found by the knowledge presented by the teacher. The idea generation process and restructuring guidelines require that the idea was developed to coincide with the objective of needs. Idea generation process requires mastery of skills by teachers through understanding regarding how an idea that should be developed and tied in with other ideas (Kay and Greenhill, 2011)

\section{Create skills definition}

Students' ability to define a matter indicate that there is an understanding in the students. Definition of an overview of a content knowledge into a framework for further elaboration deeper. Teachers are responsible for guiding students to have skills in science content something though each student may have a variety of definitions but as long as it is within the knowledge, the definition must be received (Khalid, 2010).

HOTS implementation involves the whole learning content and components in school subjects including Islamic education. Introduction of curriculum, pedagogy and assessment that emphasize this HOTS added to the basic Primary School Standard Curriculum (KSSR) which was first introduced in 2011. The creation of this curriculum to replace the Integrated Primary School Curriculum (KBSR) requires learning to apply the concept of Islamic education and practice in everyday life in line with the emphasis which is pressed in the Quran and Sunnah (Zulkipli et al., 2020).

\section{Study References}

\section{Teaching Practice for Beginning Teachers Teaching}

Beginner lessons are ranked based on the theory developed by Al-Qabisi, Robert Glaser and Ibn Khaldun include elements of lesson planning, teaching objectives and set induction.

\section{Lesson Planning}

Based on the research scientists are seven guidelines before teachers begin teaching, namely, (i) the method must be in accordance with the objectives and subjects taught (ii) the method should be suitable to the character / basic subjects taught (iii) the method must be appropriate and commensurate with the age of students (iv) the method must be able to be carried out by the teacher (iv) sufficient time to apply the relevant rules and (vii) the method selected must be compatible with the existing facilities. According Othman and Kassim (2021), 
Noh et al (2017) suggest that teachers choose methods that can provide a deeper appreciation, not only for understanding, but affects the lives of students. This method can help students focus, remember, preserve the memory and applied in daily practice.

According to the Curriculum Development Centre, Ministry of Education (2013), teaching design strategy is to build and strengthen students' interest in learning and help them to be ready to receive the next lesson and were able to continue on its own Based on the definition in the planning of teaching is the teacher's ability to analyze the implementation of all aspects of teaching and learning. This includes the selection and implementation of methods, techniques, activities, materials and time spent. (Brookhart, S. $M, 2010)$. planning strategy used as teacher-centered, student-centered, centered material or a combination of these strategies.

Teaching strategies are more important if the teacher teaches the students who have the abilities, achievements, tendencies and interests that range. Teachers should plan the approach and methods used to teach groups of various levels. Hennessey (2019). For example, in the classroom KSSR which usually consists of a group of students who are average and excellent. Teachers had to think of a teaching strategy that consists of a variety of teaching methods to meet the needs of all groups.

In addition, each classroom has obstacles and barriers of its own such as the physical, classroom facilities, values, attitudes and backgrounds of schools and students. Therefore, teachers must not only master a variety of teaching methods but more important is how to integrate and streamline rules for forming the design teaching strategies that are most effective in teaching. Noh et al (2017). The effective planning capable produce effective teaching. Planning began before the teaching is done by taking into account all the aspects of such a syllabus, student readiness, level of knowledge of students, classroom environment and teaching aids (BBM) that exist.

\section{Setting Teaching Objectives}

Al-Qabisi encourage teachers to set goals through the teaching of teachers should continuously deepen knowledge and improve themselves with teaching skills. Said (al-Qabisi, 1955) meaning:

When writing to the child and he could not spell the word and show the very beginning, he could not recognize and can not read reading.

The above statement reflects the teacher made a mistake in carrying out their duties even in terms of both teaching. Teachers also said to have committed fraud should not set a goal to be achieved by the teacher and do not teach well. Therefore, al-Qabisi show firmness by placing a teacher who does not neglect to put a neat goal in teaching assignments (Suhid, et al, 2014.).

Setting objectives also refers to the manner in which a subject is taught and the objectives to be obtained from these lessons. Every good objective should reflect the views of teaching and learning goals. It aims to help students accept and understand the lessons delivered by teachers Ail et al (2016).

According to the opinion Ulwan (2002); Suhid et al (2014), the objective is a set of assumptions that are intertwined with the process of teaching and learning as well as elements that can are gained. Through this opinion, we may conclude that any objective determination should be based on the model, or the principles of learning theory and it leads to the same learning goals. The setting objectives to be aligned with various approaches to be used in teaching, for example, from the concrete to the abstract, from simple to advanced, 
from the whole to a particular component, from the general to the specific, from far to near, from the known to the unknown the appropriateness of teaching depends on the type of teaching students and teachers involved Jasmi et al (2010)

To practice effective teaching, teacher of Islamic education should choose suitable objectives because no one objective that coincides for a student is due to several factors caused realize the diversity of levels of cognitive students but teachers should have the objective of capacity is at least $80 \%$ of students in (Ab Halim et al, 2006, 2009 and 2010). Varying objectives can also be introduced to the student's ability to understand, organize, structure, apply and synthesize ideas such as faith in Allah, His Messenger, things and the last day is in everyday life.

\section{Induction Set}

Seman, Yusoff and Embong (2017) defines a set of induction is the process skills early in the lesson that has been designed to prepare students to pursue a teaching session while. Suhid (2014). states set induction is the beginning of a teaching process in which the main objective establish is to build the mind and arouse the interest of students to pay attention to what you want to convey, while according to Boaler (2008); Robertson (2019) states set induction is the ability to start teaching before disclosed the contents or the title of a lesson. Set a good induction will give a boost to enthusiasm, attention and put the students in a state ready to receive lessons.

According to the definition, the definition above, we can conclude that set induction is a method of teaching in which fun begin teaching skills is important because at this stage the teacher narrates his ideas to the students and inculcate into the minds of the students teaching materials to be conveyed. Meanwhile, teachers also need to create interest and motivate the students have a preparedness to learn and think about the knowledge and skills that are presented by the teacher in ensuring the implementation of higher order thinking skills (HOTS) can be carried out in full.

Othman and Kassim( 2021) states that for every success in the induction set in the beginning of the lesson, the teacher shall comply with the following principles: i) Set the induction of beginning teaching is supposed to mean to the students in terms of attracting attention through fun activities and create curiosity, suitable to the student experience, ability and age. ii) Set a good induction will establish motivation to pay attention to start with something simple and does not take time. iii) Induction Set should have relevance to the content and objectives of the lesson with the teacher explains structured so that students can make connections. iv) Set Induction must be related to students' existing knowledge related topics either previously or teaching other subjects that have been studied.

\section{Statement of Problem}

Quran emphasizes the use of common elements that should involve comprehension, application, appreciation and application in everyday life. Debated the role of reason in the Qur'an with the goal of understanding how humans can use in tandem with the changing human thought in this century. This can be explained through the word of God swt means: (Al-Shafi'i, 2010).

"Do they not consider the kingdom of the heavens and the earth and everything that Allah has created, and (think) their destruction may have been nearby? So, in which more after (the coming of the Quran) will they believe?" (Al-Araf, 7: 185). 
The cultural development process of this sense applied to the educational process which is fundamental to the development of the use of reason and thought challenged with higher among students and is in line with the requirements of the Quran and Sunnah (Aminullah, 2015). Although the main focus on subjects such as math and science, subjects of Islamic education is no exception in applying the elements of higher-order thinking as it is a call that has been set in the drawing this Al-Quran (Ail et al., 2016).

Framework for the use of reason is the ability of the world community believe that the knowledge and skills needed by students to meet the challenges of the 21st century. Although there are differences in purpose terminalogy skills of the 21st century (21st century skills) among the countries in the world, but all of them focus on knowledge, skills and values (Saavedra \& Opfer, 2012). In addition, a report by consultants Kestrel Education of England and 21st Century School of the United States in 2011 states that higher-order thinking among teachers and students in Malaysia is still low. Based on research conducted for teachers implement instructional containing pedagogy based on higher order thinking skills (HOTS), it seeks to increase the understanding and practice changes in attitude (Boaler, 2008, Ministry of Education, 2014).

Based on studies conducted by (Ab. Halim et al, 2010) in a study of 89 of the 91 students were interviewed and made observations on the state of Selangor, Perak and Terengganu have found that teaching methods are often used by teachers lecture method and description in teaching Islamic education. This means that teaching and learning methods of Islamic education is teacher-centered and this affects the level of students' understanding of how to applying the lessons delivered by teachers among students. This study was supported by research (Wan Hassan et al, 2013) found that teachers of Islamic education in the teaching of Islamic education, the use of teaching aids (BBM) in the teaching of Islamic education in schools is moderate only because the focus of instruction on methods lighting only. This is contrary to the teaching practices KBAT which requires fuel used optimally to explain a problem, especially issues of faith that should be displayed using video, interactive Internet and virtual networks.

This is in line with studies carried out by Jasmi et al (2010) found that Islamic education teachers delivering lessons using $80 \%$ lecture and lecture methods in an allotted time. This causes the element to create boredom, no understanding, cannot associate with the current situation, drowsiness and loss of concentration among students. This is evidenced by a study Çelik et al (2013), the educational process is carried out to the students of the primary school level, the formation of the elements of imagination, animation, fantasy and musicals are among the approaches suitable in the process of effective teaching to the children aged712 years.

As a result, a generation of Muslims who produced it may be wise and high level of academic development but in fact the inability to translate the knowledge acquired in the form of a steady appreciation of the faith and in accordance with the laws of Allah S.W.T and this balance needs to be practiced in every student and this is HOTS needs to be done in tandem with the implementation of Islamic education of other subjects such as science and mathematics (Hashim, 2005; Khalid, 2010)

Therefore, the study looked at the practice of teacher education based on higher order thinking skills (HOTS) in the primary division of three main components, namely the start of teaching, development of teaching and teaching cover. Potential higher-order thinking skills 
are seen by (making skills category, arrange in order, make predictions, compare and contrast, generate skills and generate ideas, create a definition, metaphors and analogies create skills).

\section{Research Objective}

i) Identify lesson plans based on Higher Order Thinking Skills (HOTS) in the subject of Islamic education in primary schools.

ii) Identify the objective determination based on the teaching of Higher Order Thinking Skills (HOTS) in the subject of Islamic education in primary schools.

iii) Identify induction set of teaching based on Higher Order Thinking Skills (HOTS) in the subject of Islamic education in primary schools.

\section{Research Methodology \\ Design Review}

The design of this study is a quantitative survey method. The finding is seen through the numbers and estimates that include a certain formula. According to (Creswell, 2009) the survey method is a specific way to gather information about a large group of the population. This survey method using a questionnaire aimed at assessing which involves three main components.
a) Planning Teaching.
b) The teaching objectives.
c) Set Induction.

This study is preliminary surveys that only use questionnaires and methods of measurement based on descriptive analysis of the test means for determining the characteristics of variables without generalizes. The study used an instrument how to start teaching effectiveness based on higher order thinking skills (HOTS) has been implemented in the teaching of Islamic education.

\section{Population and Sample.}

This study involved the teachers of Islamic Education for primary schools in Malaysia, totaling 400 people with seat represents the 5 zones studies in areas involving Kedah, Selangor, Malacca, Terengganu and Sarawak. The total number of teachers of Islamic Education in Malaysia is 38, 502 people based on information from the Education Division, Ministry of Education but under the table Krejcie and Morgan (1970) through a sampling of the population, the number of suitable set of 382 people however, in this study using the 400 teachers participated in this study. The teachers were selected among the teachers who teach based on gender, academic qualifications, age and teaching experience.

\section{Research Instrument.}

The instrument or instruments used in this test is a set of questionnaires. This questionnaire is divided into two parts. At the top I found a few items regarding the background of the respondents. In part II is an instrument that consists of 30 questions related to the question of the application of KBAT in teaching. All questionnaires are examined in advance to ascertain the respondents were in the right direction to provide the information as needed. After believes the items of the questionnaire, the researchers tested the respondents Konting (1990); Pallant (2020). This questionnaire has been modified from i) an instrument of teaching based on HOTS developed by the MOE. ii) survey conducted in practice PHD thesis teaching 
by pastor Aderi Che Noh and Paharuddin Arbain. iii) KBAT assessment instrument developed by the Malaysian Examination Board

\section{Data Collection and Analysis.}

The findings obtained data will be analyzed by researchers to answer this research question. From the data obtained it is hoped that researchers can identify the practice of teaching Islamic education based on higher order thinking skills with a view from the perspective of primary school.

The reliability of the questionnaire is at a high level, namely Alpha value recorded (0.82173). SPSS 20.0 was used to find the frequency, percentage and mean Konting (1990); Pallant (2020). Table 2 shows the reliability of the components for planning teaching (0.7727), the teaching objectives (0.8905) and Induction set (0.8020).

Figure 2: Value of Coefficient Reliability Survey Instruments

\begin{tabular}{lc}
\hline Variable Value & Alpha \\
\hline & \\
\hline & \\
Planning Teaching & 0.7727 \\
The Teaching Objektives & 0.8905 \\
Induction Set & 0.8020 \\
\hline
\end{tabular}

Five-point Likert scale has been used in this study. Method score used is Strongly Disagree (STS) with a score of 1 point, Disagree (TS) with a score of 2 points, Less Sure (KP) with a score of 3 points, Agree (S) with a score of 4 points and Strongly Agree (SS) with a score of 5 points. The data obtained is analyzed using descriptive statistics such as frequencies, percentages and means.

\section{Discussion.}

Discussions related findings are based on teaching elementary component consisting of lesson planning, setting teaching objectives and set induction.

\section{The Findings Lesson Planning}

The researchers found that the application of BAT in the subject of Islamic education among primary school teachers in the planning of teaching at the high level with the mean average (4:43). Based on the findings of lesson plans, recorded the highest mean a teacher is always set design based on the analysis of the titles that have been taught before. This proves the teacher is always concerned with the design elements that will set should be based on the ability of students who obtained from the previous study. This shows the high level thinking skills element is always given emphasis by teachers of Islamic education in the classroom. But the improvements to be carried out on teachers to apply for student opinion regarding planning of instruction, because the allotted time is limited, so planning is limited habits and not be comprehensive. In terms Overall, the study found that the practice exists in the planning practices of teaching Islamic education. 


\section{The Result of the Determination of Learning Objectives}

Teachers apply HOTS on the establishment of learning objectives are at a high level with the mean average (4.39). Based on the findings for the development of teaching, had the highest mean percentage of teachers determine students' understanding through objectives in the subject to a predetermined measure. This proves the teacher using the clear objective to improve the ability of students through activities such as group work, study subjects and skills to analyze a topic in teaching. This indicates that careful planning and clear in applying the elements of higher order thinking skills (HOTS) by a teacher of Islamic education in the but the improvements to be carried out on teachers allow time for students to understand the objectives clearly, this approach is difficult to implement in primary schools because the ability to understand the concept of the goal of a teaching content in low level and require continuous guidance to ensure students understand what purpose it teaches a title.

\section{Findings Set Induction}

Teachers apply HOTS on the induction is set at a high level with the mean average (4:40). Based on the findings of set induction recorded the highest mean is related to the induction of teachers do set while teaching students to understand the relevance of the topics to be taught. This proves that teachers give students the freedom to make the application based on the level of understanding, ability and the ability of students but in the end the teacher will make a summary of the current set of induction, but part of the process of applying higher order thinking skills that are student-centered, accordingly students are exposed to the process of induction set in do. This demonstrates the understanding of Islamic education teachers in implementing a set of induction based on higher order thinking skills (HOTS) to be applied to the students.

But the study found, there are still teachers measure the induction set is only intended for the exam only to the acquisition of knowledge rather than as teachers are bound by the prescribed dosage. Besides set of induction based on the ability of students is a matter that requires consideration among Islamic education teachers. In terms of the overall picture through this initial survey found that high inherent practice of induction set of teaching Islamic education based on higher order thinking skills (HOTS) in Malaysia.

\section{Overall Findings}

This indicates that the application of HOTS indeed occur in practice initial teacher education but some improvements need to be done such as student interaction with fellow students during the process of induction set is executed, control discussions among students and teachers through the establishment of objective view student mastery through HOTS can achieved over as envisaged by the Ministry of Education. In addition, through this study, the ability of teachers to produce HOTS through an organized plan of teachers. In addition, the results of this study show some improvement in the planning stage of teaching, setting learning objectives and set induction should emphasize aspects of the following, namely, the activities carried out shall be by designing a continuous whether HOTS implemented or not and it should include Overall teaching.

\section{Conclusion}

Based on this study clearly shows the significant relationship and contribution of each component of teacher teaching especially the implementation of rehabilitation and enrichment methods, lesson planning, implementation of induction set and delivery of 
teaching content with the implementation of GPI teaching composition that integrates HOTS. In this regard, Islamic Education Teachers that implementation of teaching that integrates HOTS need to emphasize the components found in teaching with parallel aspects of knowledge, skills and high preparation

The formation of the Malaysian Education Development Plan (PPPM 2013-2025) sets six main thrusts with one of them being to produce students who are capable of thinking skills in the learning process. Yet to fulfill that desire, it becomes a requirement for Islamic Education Teachers to have the knowledge, skills and planning to implement thinking skills in the teaching process

Therefore, it is necessary for the MOE to increase exposure through training, seminars or programs that can enrich the level of knowledge of teachers, improve skills and enable preparation to ensure an effective T\&L process. This study also shows that the approach of teachers in the classroom needs to balance the level of ability of weak and excellent students which is a major contributing factor in the implementation process of the integration of HOTS. In addition, lesson planning, implementation of induction sets and delivery of teaching content also need to be enhanced and controlled by the Islamic Education Teachers because these factors are among the contributors to the implementation of the integration of HOTS in the classroom. The overall relationship of the findings in terms of theory and model can be explained through figure 1

Figure 1: Findings in theoretical terms.

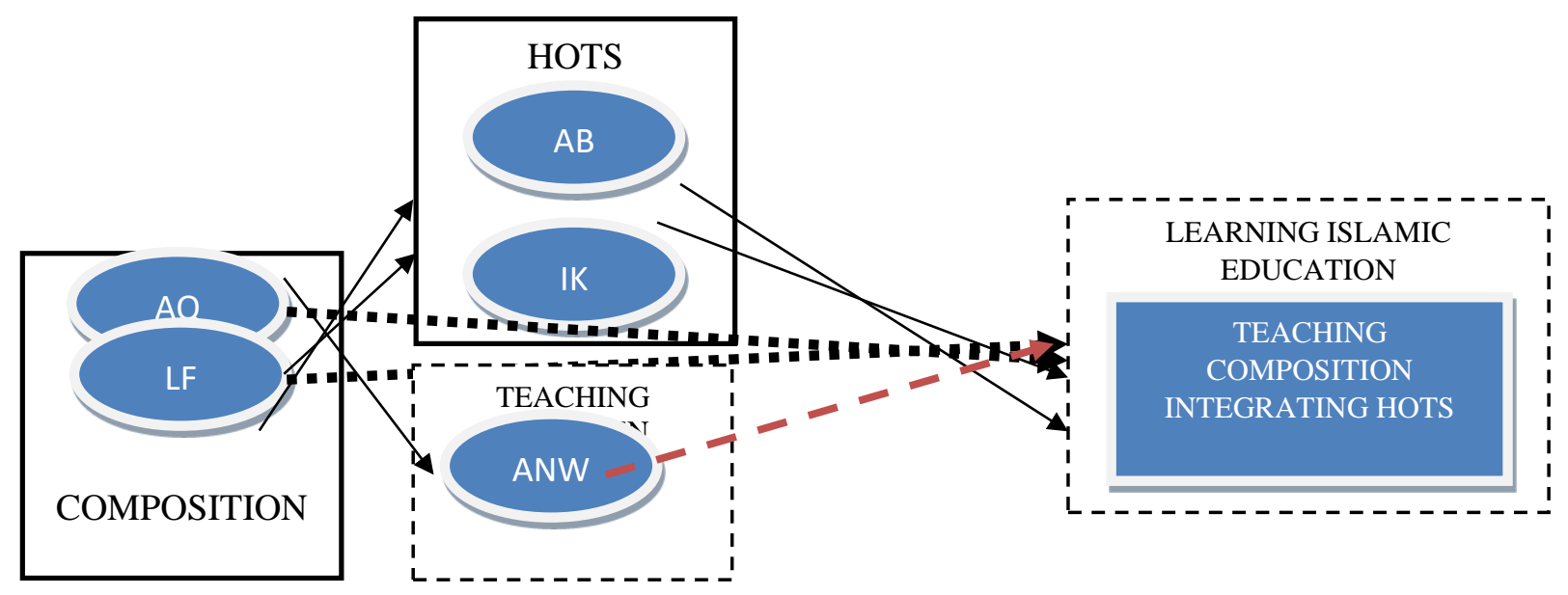

\section{Guidance}

(IK) - Ibn Khaldun's intellect ranking model

(AQ) - Al-Qabisi's teaching model

$(A B)$ - Bloom \& Anderson's taxonomic theory of thought

(LF) - Le Francois teaching model

(ANW) Abdullah Nasih 'Ulwan's teaching model. 


\section{References}

Al Quran.

Ail, N. M. M., \& Abdullah, Z. (2016). Murabbi Leadership Model in MRSM and Malaysian Secondary Schools. Educational Leader (Pemimpin Pendidikan), 4, 124-136.

Aminullah, E. (2015). Learning, R\&D Intensity and Economic Prosperity in Low R\&D countries (LRDCs): envisioning the Indonesian future. In Yogyakarta: Paper presented in Asialics 2015 Conference, Yogyakarta, November (pp. 15-17).

Boaler, J. (2008). Promoting 'relational equity' and high mathematics achievement through an innovative mixed-ability approach. British Educational Research Journal, 34(2), 167194.

Brookhart, S. M. (2010). How to assess higher-order thinking skills in your classroom. ASCD.

Çelik, S., Arikan, A., \& Caner, M. (2013). In the Eyes of Turkish EFL Learners: What Makes an Effective Foreign Language Teacher?. Online Submission.

Cohen, L. (2007). Lawrence Manion, and Keith Morrison. Research methods in education.

Creswell, J. W. (2002). Educational research: Planning, conducting, and evaluating quantitative (pp. 146-166). Upper Saddle River, NJ: Prentice Hall.

Hashim, R. (2005). Rethinking Islamic education in facing the challenges of the twenty-first century. American Journal of Islamic Social Sciences, 22(4), 133.

Hennessey, B. A. (2019). 18 Motivation and Creativity. The Cambridge Handbook of Creativity, 374.

Jasmi, K. A., Tamuri, A. H., Hamzah, M. I. M., \& Izham, M. (2010). Faktor Pentadbir dan Pengetua dalam kecemerlangan Guru Cemerlang Pendidikan Islam dan Guru di sekolah menengah: Satu kajian kes. Journal of Islamic and Arabic Education, 2(1), 1320.

Kay, K., \& Greenhill, V. (2011). Twenty-first century students need 21st century skills. In Bringing schools into the 21st century (pp. 41-65). Springer, Dordrecht.

Khalid, T. (2010). An integrated inquiry activity in an elementary teaching methods classroom. Science Activities, 47(1), 29-34.

Konting, M. M. (1990). Kaedah penyelidikan pendidikan. Dewan Bahasa dan Pustaka.

Krejcie, R. V., \& Morgan, D. W. (1970). Determining sample size for research activities. Educational and psychological measurement, 30(3), 607-610.

Nagappan, R. (1998). Teaching higher-order thinking skills in language classrooms: The need for transformation of teaching practice. Michigan State University.

Noh, M. A. C., Ajmain, M. T., \& Rahman, E. Z. E. A. (2017). Teachers' Practice of Higher Order Thinking Skills in the Lesson of Islamic Education. 3(2), 1-13

Othman, M. S., \& Kassim, A. Y. (2021). Keberkesanan Amalan Pengajaran Guru Pendidikan Islam Menerusi Kemahiran Berfikir Aras Tinggi (Kbat) Di Dalam Mata Pelajaran Pendidikan Islam Sekolah Rendah Negeri Perak (The Effectiveness of Teaching Practice among the Islamic Education Teachers Through High Order Thinking Skills (HOTS) in The Islamic Education Subject in The State of Perak). UMRAN-International Journal of Islamic and Civilizational Studies, 8(1), 75-86.

Pallant, J. (2020). SPSS survival manual: A step by step guide to data analysis using IBM SPSS. Routledge.

Robertson, P. (2019). Senior Editor: Paul Robertson.

Saavedra, A. R., \& Opfer, V. D. (2012). Learning 21st-century skills requires 21st-century teaching. Phi Delta Kappan, 94(2), 8-13. 
Seman, S. C., Yusoff, W. M. W., \& Embong, R. (2017). Teachers challenges in teaching and learning for higher order thinking skills (HOTS) in primary school. International Journal of Asian Social Science, 7(7), 534-545.

Suhid, A., Fakhruddin, F. M., Roslan, S., Mutalib, L. A., \& Noh, M. A. C. (2014). Private Islamic primary school teachers' commitment in human capital development in Malaysia. Mediterranean Journal of Social Sciences, 5(27 P2), 766.

Ulwan, A. N. (2002). Pendidikan Anak dalam Islam, alih bahasa Jamaluddin Miri. Cet. ke-3, Jakarta: Pustaka Amani.

Zulkipli, Z. A., Yusof, M. M. M., Ibrahim, N., \& Dalim, S. F. (2020). Identifying Scientific Reasoning Skills of Science Education Students. Asian Journal of University Education, 16(3), 275-280. 